\title{
Sociocultural Perspectives of Science and Learning: Contributions on Pedagogical Practices on STEM teachers in Service
}

\author{
Milena Alcocer Tocora ${ }^{1}$, Carola Hernandez Hernandez ${ }^{1}$ \\ ${ }^{1}$ Los Andes University, Bogotá, Colombia \\ Correspondence: Milena Alcocer Tocora, Los Andes University, Bogotá, Colombia. \\ E-mail:mr.alcocer10@uniandes.edu.co
}

Received: August 4, 2020

Accepted: September 15, 2020

Online Published: September 16, 2020

doi:10.11114/jets.v8i10.4961

URL: https://doi.org/10.11114/jets.v8i10.4961

\begin{abstract}
This research study contributes to science teacher training by analyzing a curriculum that takes in sociocultural perspectives of science and learning in in-service teachers' pedagogical practices. It is a qualitative study with a critical hermeneutic methodology. The method used was a multiple case study, which inquires by exploring different cases in depth. The information was collected within the framework of a postgraduate training program, with in-service teachers from the areas of Science, Technology, Engineering, and Mathematics (STEM), in two settings: the training program and the observation of their pedagogical practice. Results show that this sociocultural perspective of the curriculum contributed to the pedagogical practices of the teachers under study in six different ways: i) generation of new understandings of science, learning, and the discipline they teach; ii) identification of other meanings for the concepts they teach; iii) changes in-class activities that help to recognize the identity of the scientific community; iv) inclusion of strategies that foster the negotiation of meaning in the community; v) changes in the evaluation strategies, giving more importance to feedback; and vi) generation of reflexive processes about the pedagogical practice in a more conscious way.
\end{abstract}

Keywords: teacher training, pedagogical practice, sociocultural perspective, STEM teaching practices

\section{Introduction}

Researching pedagogical practices is of most importance in the transformation of education from the classroom reality. In this regard, some studies show that the countries that have managed to introduce research as a core line in their education system have improved their education standards, especially in science (Cofré et al., 2010; Jakku-Sihvonen \& Niemi, 2007; Levy, 1998).

Different studies have addressed this topic from different perspectives for the past 20 years in Colombia's particular context. Some of them have been mentioned in states of art about research on education and teaching of natural science (Alcocer \& Hernández, 2020; Hernández, 2001; Vasco, 1993; Zambrano, 2015), which state that since 1993 most of the research products related to teaching practices have been developed by research groups within teacher training programs.

Then again, other studies show that there have been no conclusive changes in the practices yet, and identify decontextualized practices are prevalently focused on the transmission of concepts (Cofré et al., 2015; Gallego R., Perez R., \& Franco, 2014; Gallego R., Pérez R., Gallego, \& Torres N., 2004; Garcia S., Maldonado, Perry, Rodriguez, \& Saavedra, 2013; Martínez J. \& Benarroch, 2013; Ministerio de Educación Nacional MEN, 2014; Misas, 2004; Torres, Badillo \& Miranda, 2006; Vallejo, 2014; Zambrano, 2015; Ortega N., Ordoñez R., Gomez-Vahos J. \& Florez M, 2018). Moreover, the poor results of Colombian primary and middle school students in standardized national and international tests in all areas -particularly in science- reveal there is a considerable gap between what the children and youngsters are expected to learn and what they actually learn (Garcia J., 2014; S. Garcia et al., 2013; Ministerio de Educación Nacional MEN, 2014; Vélaz, 2009).

Aiming at a more profound comprehension of these problems, researchers from different contexts have found that part of the issue lies in the absence of curricula that foster a systematic reflection about the nature of science (NOS), involving historical and epistemological components in the learning of disciplinary concepts (Gallego et al., 2014; Izquierdo, García, Quintanilla, \& Adúriz, 2016; Kruse, Easter, Edgerly, Seebach, \& Patel, 2017; Vázquez, A., Acevedo, J., Manasero, 2000; Zambrano, 2015; Mesci, G., Schwartz, R.S. \& Pleasants, B.A, 2020). To counteract this problem, it is 
necessary to develop theoretical and methodological constructs that directly affect the practice.

In this sense, Porlán A; Rivero A and Martin Del Pozo (1998) proposed a series of categories to identify relations between the conceptions of science, the construction of professional knowledge, and pedagogical practice. They concluded that professional knowledge construction would improve as teachers broaden their epistemological perspective of science (Porlán, Rivero, \& Martín, 1998).

According to Porlán (1989), science conceptions may be classified into four types: rational, radical empiricism, moderate empiricism, and alternative. Rational comprehension implies a reduced view of science and sees knowledge as a human mind product, generated individually through a logical rigor, assuming science as truth. From this perspective, knowledge is neither part of the reality nor obtained by observation since senses may distort reality, impeding authentic knowledge.

On the other hand, radical empiricism proposes that by induction, the observation of reality may enable objective and real knowledge, which is, in turn, its reflection (objectivism, absolutism, and realism). In the moderate empiricism, the generation of hypotheses and experimentation take the place of observation as the core of the scientific process. However, these can be generated in both individual and collective ways. Finally, alternative comprehension identifies a new image of science; it recognizes it as an activity conditioned by social and historical contexts; furthermore, it conceives science as the community's product.

In this sense, Porlán A; Rivero A and Martin Del Pozo (1998) proposed a series of categories to identify relations between the conceptions of science, the construction of professional knowledge, and pedagogical practice. They concluded that professional knowledge construction would improve as teachers broaden their epistemological perspective of science (Porlán, Rivero, \& Martín, 1998).

According to the sociocultural theory of Wenger (1998), scientific communities behave as communities of practice. These communities are social groups that develop knowledge through continuous interaction, and by sharing learning based on reflecting on practical experiences; in this way, it generates identity. Scientific communities are identified by sharing a common interest, probing in a particular knowledge systematically by negotiating meanings, developing models that explain the knowledge developed, communicating their findings in an argumentative way, and validating the knowledge produced by its members.

For the community and its members, the negotiation of meaning represents a way of experiencing the world and its commitment. Thus, learning is understood as the negotiation of meanings, and it is a process that we do permanently as human beings as we interact.

On these grounds, teaching and educative practices must be analyzed from a more comprehensive view. Carr W. (1995) suggests they must be studied from teachers' ideas and experiences as their main actors. According to him, pedagogical practice is built from four dimensions: personal and professional intentions, social interactions, the historical context of the teacher, and the political context of their actions. In this sense, the practice comprises the planned strategies and activities and the way they are put into practice in the classroom.

On these grounds, the research question that this study intends to respond is: what are the contributions of a STEM curriculum based on a sociocultural understanding of science and learning to the pedagogical practice of teachers in service?

\section{Methodology}

This study used the methodology of multiple case study. According to Stake (1998), a case study is an analysis of the particularity and complexity of a singular case to get to understand its activity in a specific situation. The multiple case study enables inquiring about a phenomenon, population, or general condition by probing in several cases. By identifying their differences and similarities in detail, the dimensions of the problem under study are clearly revealed, while enabling a theorization (Yin, 2009).

Thus, the information collected was analyzed from a critical-hermeneutical perspective that provides both a general and a detailed comprehension of the phenomenon, consolidating a valid and pertinent discourse about the topic's reality under study (Alvesson \& Skoldberg, 2009; Goetz \& Lecompte, 1988).

Three cases of STEM in-service teachers of a postgraduate program on education in Colombia were analyzed (see Table 1). These teachers were selected for convenience, given that they had voluntarily enrolled to participate in the course: "Pedagogies for the development of scientific thinking (PDST)". 
Table 1. Participants of the study

\begin{tabular}{|c|c|c|c|c|}
\hline Pseudonym & Gen & Title & $\begin{array}{l}\text { Complementary and postgraduate } \\
\text { training }\end{array}$ & $\begin{array}{l}\text { Educative level in which they } \\
\text { teach }\end{array}$ \\
\hline Sol & Fem & Graduate & \multirow{4}{*}{$\begin{array}{l}\text { Master's degree in education } \\
\text { Diploma in pedagogy, Master's degree } \\
\text { in education. } \\
\text { Master's Disciplinary degree, Master's } \\
\text { degree in education }\end{array}$} & Primary and Middle-sec \\
\hline Jorge & Masc & Engineer & & Primary and Middle-sec \\
\hline Flor & Fem & Engineer & & University \\
\hline & & & & \\
\hline
\end{tabular}

Source: own elaboration

The information was collected in two settings established for this research: first, during the participation in the course (training), and second, during the observation of 35 hours of pedagogical practice and three sessions of reflection per teacher about their task. Table 2 shows the instruments used in each one of the phases of the study.

Table 2. List of instruments in each one of the phases of the study

\begin{tabular}{l|l}
\hline Phases & Instruments \\
\hline Training phase & $\begin{array}{l}\text { Questionnaires of open questions, Likert-type survey, virtual forums, written documents } \\
\text { prepared by the teachers in training, interviews with the teachers, audio recordings of class } \\
\text { discussions, and field journal. } \\
\text { Interviews with participant teachers, students and work peers, class plans, learning guidelines, } \\
\text { and field journal. }\end{array}$ \\
\hline
\end{tabular}

Source: own elaboration

The following was considered: protecting the privacy of the participants, the contexts and the data collected, respecting the time frameworks of the participants, their availability to participate in the study, and the agreement to collect the information. Additionally, all participants signed informed consent. Hence, we used pseudonyms in this report and will not give details that may reveal the participants' identity and contexts.

The analysis of the information collected was done with the software Nvivo, version 11.4.0. The categories of analysis were established according to the theory of Carr's educative practice (1995) and that of practice communities proposed by Wenger (1998).

Next, we will describe the categories established for the analysis:

i) Context and motivations: The teacher's story is described in terms of their motivations, general experience, and teaching experience.

ii) Transformation of the understanding of science, scientific thinking and scientific community: This analysis describes the changes in the teachers' conceptions of science due to the training, based on an adaptation of the four beliefs about science described by Porlán (1989), and Porlán A; Rivero A \& Martin del Pozo (1998), namely Rationalism, Radical Empiricism, Moderate Empiricism, and Alternative.

- Sociocultural understandings and development of the pedagogical practice: Five sub-categories were used for this analysis (three of them were established from an adaptation of the sociocultural theory of learning proposed by Wenger, 1998): a) criteria and intentions for class planning; b) strategies that familiarize the students with the identity of the scientific community; c) strategies for the negotiation of meanings in the community; d) Approach to the disciplinary concepts and scientific thought, and e) Strategies for the evaluation of learning.

iii) Contributions to the processes of reflection on the practice: This category identifies reflexive processes in teachers and systematization strategies or activities that may result from such processes.

\section{Results}

The result analysis is presented as indicated by the multiple case study methodology: each case is described based on the analysis categories established for the study.

\subsection{Case 1: Teacher Sol}

Sol is a teacher with 16 years' experience; her eyes express the character of a strong woman who firmly believes in education. She has a degree in Chemistry and Biology, worked in the private sector for ten years, and has been working for the past seven years in a public school in the south of Bogota. 
Her work in public education started with low-socioeconomic level children from primary school. Her experience was both beautiful and shocking; in addition to working in all areas, she had to deal with these children's complex reality, and almost daily, she would deal with maltreatment cases, malnutrition, and abandonment. Given the deep pain she felt for this reality, she requested a change, and currently, she is working with children from 8th grade. There are problems here as well, but she feels she can cope with them better. The groups taught by Sol have 41 students each, and that makes her task difficult. She likes working on processes and has asked to teach the same groups from sixth grade to the highest grade possible.

She firmly believes in the importance of her work for the transformation of society, and hence she is committed to improving her professional background and always giving the best of her to her students. As a result, she applied for the Master's program in education offered by one of the country's best universities when the city's government offered a scholarship program. For Sol, studying this Master's degree was revealing:

Sol: “...studying the Master's had its origin in need, because I always felt that I lacked a research-related aspect in my practice; I mean, I worked and did nice things with them, but I asked myself: what about this? What is the aim of this? What am I doing this for? It was like an internal need, a personal conflict... So I decided that I needed to incorporate more research into what I do" (Interview 1, Case 01).

Sol: “... since I started the Master's, I realized that it was exactly what I was looking for (...) I learned different ways of doing research, applying them, and improving the whole process, not only in the personal sphere of the practice but also in sharing it with my peers that are also interested in the same thing. Besides, I learned that educative research is a need at this moment" (Interview 1, Case 01).

The curricular design of the Master's involves courses that imply developing short research projects; this enabled Sol to achieve the objectives she had set, which made her consider that her educative experience in the program was amazing.

For Sol, the PDST course was a scenario in which she could reflect about some aspects that -according to her- she did not know, and which are essential for teaching and learning science at any educative level:

Sol: "...There are several things in the course that were appealing to me; for example, I had never thought about the epistemology of science, and I realized that it is fundamental. Graduate programs never prepare you in that sense, and during the practice, I barely thought about knowing more about it. Another important thing is that -although I knew about scientific thinking skills- I had never put them into practice (...) Scientific thinking is not the same as any other type of thinking, and at this moment, I have to turn to that skill so that the students give more sense and meaning to a class." (Interview 2, Case 01). actually

After developing the course and reflecting that in her 16 years of pedagogical practice in the area, she had never worked on these ideas, she recognizes that they are of great value to address science concepts in the classroom:

“...the course enables conceiving a culture of scientific organization based on the study of the models. Thus, there is an opportunity to think about a different way of teaching, where students are always organizing their mental maps and their procedures... They are always working around that. Ultimately, that gives them more structured thinking for their lives." (Interview 2, Case 01).

When the course started, Sol expressed she was interested in improving her practice and mentioned other expectations about what the course could give her, including technical alternatives for her classes. Nevertheless, she found that the course's first activity inquired about the participants' different comprehensions about three essential learning and science teaching concepts. In the Likert-type test on the concept of science, she agreed with the statement that "science is a path towards truth" and "science is made by upstanding individuals" and disagreed with the statement that "science is a lineal accumulation of findings". As regards teaching science, Sol expressed that it is necessary to know the discipline and know its teaching, scientific models, and what it really means.

Concerning the concept of scientific thinking, Sol considered that it is related to:

"the way in which the cognitive abilities enable someone to understand the processes of living things and their surroundings. Some abilities are related to aspects such as: asking questions, analyzing, synthetizing, concluding, verifying, contrasting, and communicating." (Questionnaire 1, Case 01)

Her responses show that the meaning of the scientific community is not clear for her:

“...I agree that science has been built by groups of specialists...” (Likert-type test, Questionnaire 3, Case 01)

“... learning science goes beyond the knowledge of what the scientific community publishes; it must be a reflexive and analytical act of individual thought around science..." (Survey, Questionnaire 3, Case 01)

On the one hand, she recognizes science as an individual construction, and on the other hand, she disregards the importance of the scientific community's knowledge. 
At the end of the course, Sol showed the integration of new elements to her comprehension of science, scientific thinking, and the scientific community. For example, she wrote:

"...epistemology (...) is a clear invitation to analyze the process of science throughout time and its relationship with the present time. Likewise, it enables us to identify the mechanisms to change paradigms and improve classroom strategies." (Discussion Forum 2, Case 01)

“...science is a rational construction that enables inquiring about the logic structure of the phenomena that rule nature, to build explanatory models in the classroom (...) it also proposes that a collective process can produce scientific knowledge; this implies the active participation of the students to empower their own process." (Final reflection of the course, Case 01)

Sol was very blunt to mention the following:

"Before I used to work on a lineal sequence of contents, everything was quite flat, like lacking sense... The thing is I have to cover a wide range of planned contents, so you devote to the topics but not to the thinking. " (Interview 2, Case 01).

Sol's reflection shows that this kind of practice is part of a culture reproduced in and by many teachers. The course's training proposal broke this model since she recognized and understood other ways of addressing the content without disregarding scientific knowledge development.

Also, her classes' analysis showed from the first moment a high commitment to the learning of her students and a special affection of her students for her. She inspires respect, but at the same time, closeness. Sol knows their realities and is concerned about contributing to the demanding conditions of their context. Her practice showed a bet for meaningful learning.

In her planner, Sol considers the institutional guidelines, the national standards for natural sciences (NSA), and her knowledge about the discipline. Thus, she identifies the contents, achievements, and competences of her students based on three dimensions: cognitive dimension, related to the elaboration of schemes, maps, or models; procedural dimension, referring to experimental works or applications; and the attitudinal dimension, which aims at strengthening the being.

Sol designs learning guidelines and workshops for the three periods of the school year in her school. She uses several sources for the guidelines and workshops; however, she focuses on activities that she takes from a textbook that considers excellent support for her work and balances the activities that she plans and what she wants her students to learn.

Sol: "The book (...) has excellent workshops that involve everything, and I do not see the need to do something different. I like it very much. I also try to take other things and questions from specialized books. It is necessary because some textbooks are too simple and transform scientific language into a basic language that does not help students. " (Interview 2, Case 01).

“... the teacher starts the class by giving the instruction to start developing the workshop planned for today's class, (...) when I checked the workshop, I found that it is part of the activities in the book that the teacher uses as a guide (...). Besides, the workshop has some open questions and other matching-answer questions aimed at probing in the content." (Field journal- Class 6, Case 01).

This text reveals that the activities used foster scientific thinking skills such as observation, relation, explanation, and sometimes problem resolution. It is why Sol uses this book as a guideline for her classwork.

The class observations show that she uses different activities to familiarize the students with the scientific community's practices. For example, when studying the bone system, the students asked the following questions in class: at what age do we stop growing? Why do we stop growing? Is it true that older people become shorter? (Field journal Class 5, Case 01). In all the classes observed, there was an evident interest in Sol to answer these questions in the best way possible.

Also, two lab practices were observed (structure of the bones and muscular system), and the development of a model of the bone structure; the latter is related to experimental demonstrations.

"the teacher tells the students to make a 3D model of a bone in plasticine. She clarifies that the model must show the different parts of the bone. Each student has 40 minutes to develop the model.” (Field journal - Class 3, Case 01)

“...we are in the lab; students like this place (...) The teacher comes in, and hands out a guide that describes the case of a dog that finds some long human bones and the mission of the students is to identify what kind of bones they are according to their morphology..." (Field journal - Class 5, Case 01)

Sol uses conceptual maps frequently. These schemes help the students synthetize the scientific concepts that they are learning in the classroom. She has been applying this strategy for a short time, and it is related to her Master's paper; there, she found that this is a great tool to support her students' learning because it gives them a complete vision about the topic they are studying. Then again, there were no strategies, including NOS, history, or epistemology of science. For Sol, 
it is not clear yet how to incorporate these aspects into the content. There is also a challenging to promote community work. In the class observations, the following was identified:

"...Today, as always, the desks are organized in lines in the classroom. This display fosters individual work, and I have observed this in the two courses (...) Apparently, for the teacher, this is a good way to control what her students do." (Field journal - Class 7, Case 01)

Sol confirms this observation:

"I like working in individual activities because in this way I can assure that each student is building their own knowledge. When I make them work in groups, only a few ones end up working. That is also why I ask to see their notebooks frequently (...). At first, I organized the desks in a circle, but that ended up in a mess: things flew around the room. I think they are not ready for this kind of setting..." (Interview 2, Case 01).

Nevertheless, in some of the classes observed, while Sol was checking the notebooks, her students supported each other in developing the workshops and shared knowledge, although sometimes not in the best way:

"...After the activity of experimentation, the students are talking about the smoke and the gas indiscriminately. In their conversation, these two concepts seem to be the same. I think that this would be a great opportunity to probe the subject and clarify the differences between smoke and gas." (Field journal- Class 8, Case 01)

Although Sol was aware of these informal interactions, she did not realize they could be learning opportunities related to the class and lost these chances for interaction and negotiation of meanings.

The teacher included the other two types of learning scenarios in her practice: laboratories and the development of small projects that involve answering questions by means of experimentation. In this last practice, the students must explain the scientific foundation of what happens in the demonstration and describe the methodology they used to design the experiment. For example, in one of the projects developed, they were learning about fluids, and a student showed how the density of smoke is affected inside a bottle.

In general, the students have fun and positively value these activities:

“...the teacher has been implementing the experiments for a short while. But it is cool because we have much fun looking at what we do and what the others do (...) we use different materials, and they are easy to make." (Interview with students, Case 01)

Concerning teacher-student interactions, in the classes observed, it was evident that the students feel affection for Sol and great respect. This may be deduced by the kind treatment the students give her and the students' permanent willingness to do the activities she proposes in class.

Sol holds a dedicated space for her students, giving them the freedom to ask about what they do not understand; she also gives exciting explanations contextualized to her students' particular needs:

"Today, in class, the teacher explains why football players can develop their calf muscles more. This motivates the students notably, especially boys. There are many questions about this topic, and the teacher tries to answer them." (Field journal - Class 6, Case 01)

Sol makes sure that every student completes the activities that she proposes in class and does a detailed follow-up of completing the activities (workshops and homework) by checking the notebooks; this is her systematization instrument of the students 'work.

She uses written individual evaluations aimed at integrating competences in line with the national standards. These evaluations have two types of questions: multiple choice and open questions. Lab reports and mini-projects also have a grade. In these, she evaluates the ability to observe and argue about the topics under study.

The school also does two types of virtual evaluations: one evaluation of competences related to the discipline and a self-evaluation. According to Sol's experience, these evaluations are not taken seriously by the students because they can complete them at home, and the tests have a low representation in the final grade (15\%). Sol participates in the design of these evaluations with a bank of questions related to the topics addressed in class.

As regards to the reflection processes promoted by the teacher, we found that although she has always had a reflexive attitude about what she does in her class, she only managed to systematize these reflections in her paper and the development of applied projects in her classroom, promoted by the training program. In this regard, she states:

“...I have a field journal, but I have not been constant, so I have it by weeks (...) I have been writing it since last year; we did it for the action research seminar. At that moment, and for the paper, I used to write it more often. Now I do it weekly, but it is not a structured work." (Interview 2, Case 01). 
However, we were never able to see this field journal. According to her, the load of activities in her work does not give her space to write the journal rigorously, and hence, it is not possible to permanently systematize her practice.

\subsection{Case 2. Teacher Jorge}

Jorge is a young teacher with six years of experience who loves mathematics. He is a shy man for whom speaking in public is a challenge. He is an engineer and became a teacher because he won a teacher contest to work as a math teacher in a public school in an underprivileged city sector. He was motivated by his love for math and the convenience of having a stable job in a context in which work opportunities were scarce.

His first day of class was not a pleasant experience due to his shyness:

"...so, introducing myself to a group was scary. I introduced myself nervously; I did not know what to do. Even now, every time I start with a new group, I feel nervous... In the last two years, I have felt calmer, I have improved..." (Interview 1, Case 02)

Currently, Jorge works with students from the sixth, eighth, ninth, and tenth grades. Each group has around 25 students, and he thinks that learning to control these groups has been difficult for him. He is in charge of the math class, but in the tenth, he teaches a class that he likes very much: Mathematical Thinking, which -according to him- "is not subject to the guidelines of the Ministry of Education; it is a freer class." (Interview 1, Case 02).

When he started working as a teacher, Jorge had to take a pedagogical training course. In this course, he could incorporate the theoretical contents of pedagogy that he had never seen before.

“...I had never been close to pedagogy. There were many interesting things in the course that I did not know... Learning how to explain something, never before..." (Interview 1, Case 02).

The Master's program appeared as a new opportunity to improve his practice by means of pedagogical training. In this sense, he thinks he has learned much, and although he still has difficulties, he has been able to put into practice some of the elements he has learned:

"The Master's has been a mixture of many things. So, this experience tells me what I have done right and what I have done wrong. It has made me more reflexive... So, I do self-evaluation as a teacher. For example, last semester, while I was writing my paper and studying the course, I reflected on my practice. I recorded my classes... My group management was terrible... I was not very effective, and this year, I am using more the school's tools. Now I listen more to the students, and if I have to stop the class from asking for an order, I do it. Before stopping the class to talk with the students for me was a loss of time." (Interview 1, Case 02).

Concerning the PDST course, Jorge thinks that he could reflect on science in this setting, which so far was an unknown world for him. Also, he was able to reflect on the importance of scientific thinking for society. For example, he could think about the importance of mathematics for his students:

“...this course taught me how to make the students have a way of thinking that is useful for them in this society. ...math is useful for them in life and with a tool as math they can make better decisions (...) We learned how the courses are taught by projects, not only evaluations and workshops" (Interview 1, Case 02).

His initial understandings about the concepts of the course were unclear. For instance, regarding the concept of science, he had limited comprehensions expressed in responses such as science is a path to truth, and science is not a product of a group of specialists, and in his disagreement with "science is a lineal accumulation of discoveries." (Responses to Likert-type test, Case 02).

Concerning science teaching, Jorge agrees that to teach science knowledge about the discipline is not enough. Knowing about its teaching and scientific models is also of great importance.

On the other hand, his understandings about scientific thought were ambiguous:

"It is the ability to think in a way that nature itself gives us the necessary tools to solve our problems. It is a way to see the world with the idea of explaining it by means of theories that have sound foundations; in other words, that they can be demonstrated or experimented with being proven and verified according to the community in which we are." (Questionnaire 1, Case 02)

Jorge identified the relation between mathematics and scientific thought in the procedures to solve exercises or in demonstrations. Also, he thinks that it is difficult for him to develop this kind of thought in all of his students:

"I think that I can develop it in a few students since I devote most of the time to the norms established to solve the exercises. Sometimes I do it when I do demonstrations of the topic we are studying." (Questionnaire 1, Case 02)

Regarding the scientific community, Jorge defined it as a group of experts in charge of teaching science and increasing 
learning among all the members through socialization.

These ideas were elaborated throughout the course, as shown in his final reflection and the final modules' contributions:

"Science is made by the social groups that comprise it, its scientific groups, and how the new members form a community." (Forum Module 4, Case 02)

"...I learned how important the history and the epistemology of a specific science are; sometimes we do not know this, and it can show us the obstacles that humanity has had to solve a problem (...) this is very important because it is a motivation factor for the students. (Final reflection, Case 02)

"Learning this subject was very important to me. I always thought that the scientific method was the only way to make science." (Final reflection, Case 02).

During the first interview, we asked Jorge to characterize his practice.

"Well...The bell rings, I wait for the students to come, give 5 minutes to start, roll-call, mark the students that are late, absences, I ask a student if someone is skipping or not I bring the students' record so that the parents are aware of the situation: did not come to class. Then, depending on what we are studying, I pick an exercise, write it on the board, explain it, ask if they have questions, explain a different example, and normally I leave a workshop. Before, I used to do it by groups, and now I try to leave it for individual work due to [my difficulty with] group management." (Interview 1, Case 02)

The outlook did not seem encouraging at all, but we found he was aware of his weaknesses and eager to work on them. Proof of this is that Jorge did his Master's paper about his practice, focusing on understanding the negotiation of meanings in his class by analyzing his class recordings. There, he could see his problem with group management and found progress compared to what he did at the beginning of his teaching career. Now Jorge thinks that he has gained more control over the group.

Nonetheless, the class observations showed critical communication problems in the classroom: Jorge is a reserved teacher that does not show interest in the students' needs as long as he can teach the contents in his planning, and his students do the exercises that he writes on the board correctly.

When inquired about his planning, Jorge said:

“...For the planning, we take into account the topics, the Ministry's guidelines for mathematics, and we divide that by different types of knowledge. So, there are four types of knowledge: Knowing how to think, knowing how to do, knowing how to be, and there is another one that I forgot. Then, with those four categories of knowledge, we build a plan for each period. This plan involves an explanation of concepts regarding certain topics and doing the exercises correctly." (Interview 1, Case 02).

The contents' sequence is determined by a book of his preference that corresponds to his teaching degree. He does not develop learning guidelines but proposes what he calls "a series of workshops". These workshops are structured based on some exercises previously selected, which he copies every day on the board, as seen in the class observations:

“...the teacher explained four examples of exercises on the board about the topic: multiplication of polynomial functions. Here I would like to highlight that few students are paying attention to the explanation, but the teacher is not aware of this; after asking the students if they understood, he writes 24 exercises on the board. Then he says that these exercises must be solved in the remaining class time." (Field journal- Class 1, Case 02)

It was evident here that there are no scenarios to contextualize the exercises proposed or the contents taught. At the end of the study, the teacher said:

"After the course, I understand that history and epistemology of science are important for learning. However, it is difficult for me to include this in practice. I think that it cannot be done with all the topics. For example, in my paper, I worked around the topic of statistics, in which I worked with the history of statistics... But to teach algebra, it is more difficult." (Interview 2, Case 02)

Furthermore, the teacher does not develop activities of collaborative work. All the workshops he proposes are developed individually. For Jorge, making the students work alone is the best way to keep control over the class and do a personalized follow-up of each student:

"before developing the workshops, I used to form two big groups, and this was a mess. Now I let them work in small groups, but they must deliver individually." (Interview 2, Case 02)

The approach to the class's disciplinary content is made by developing workshops that are decontextualized from the students' needs. Problem-solving is not encouraged, and the class is monotonous. The extracts shown below are evidence of the dynamic that characterizes all his classes: 
“Workshops are important because the students can solve exercises to practice what we have done in class." (Interview 2, Case 02)

"The class starts, and the teacher does the roll-call. He explains some exercises on the board and then goes place by place to see what they are doing. Then, he leaves 15 exercises on the board and asks the students to solve them before the class is over." (Field Journal, - Class 1, Case 02)

"...the class starts with the roll-call and the handing out of notebooks. While the teacher looks in the book, the students are fooling around (...); today's topic is: "zeros in a quadratic function". Again, the teacher explains some exercises on the board; some students are not paying attention. Then, the teacher continued with the workshop and left eight exercises for them to solve..." (Field journal - Class 6, Case 02)

The relation between the teacher and the students is not very close. It is limited to explaining the exercises and grading the notebooks. In general, the teacher devotes time to answering questions about the explanations he gives to the exercises. Nonetheless, there are not many questions. Most students do not pay attention or do not dare to ask questions:

“...the teacher explains the exercises. However, he spent time explaining something it is simple for the students. In other words, it seems as if he was explaining something the students already know. Hence, most students express their disapproval and ask him to explain faster. The teacher ignores their request and says it is essential that everyone understands. The students do other activities and do not pay attention, but the teacher apparently does not care. (Field journal - Class 3)

"While the teacher explains, many are still focused on other activities - the teacher probes in the explanation going back to the beginning of the lesson. Many students express their confusion and say they already studied that topic. I see here that the teacher generates more confusion in his eagerness to explain everything very well. It seems as if he is running in circles around a really not that complex topic." (Field journal - Class 6)

The situations described in the previous quotes took place in several classes and shows the teacher's disconnection from the students' interests and the students from the teacher's educational purposes. Although Jorge has manifested several times that now he has more control over the class, he still does not manage to generate empathy with his students, as confirmed by the following quote:

"... the main problem is the teacher is that he does not set clear limits in the class; besides, he is always in the mathematics topic that he is explaining, and he gets disconnected from what we do (...) He always gives us exercises and then grades them (...) He is not like other teachers that become closer to us..." (Taken from an interview with students)

Although Jorge's school has clear guidelines for evaluation, he did not show evaluation practices consistent with these guidelines. For example, in the plan designed, he included the criterion: "Knows how to make relations: Develops attitudes for group work and listens respectfully the solution proposals of others". However, as we have shown, in his classes, he does not develop activities that imply collaborative work to observe this knowledge, and his main form of evaluation is reviewing the workshops developed in the students' notebooks.

Moreover, Jorge does some individual written evaluations related to the exercises that the students do in class. There was no comprehensive evaluation of their learning.

Jorge shows a reflexive process on his practice from the beginning of his work as a teacher. He has always understood that there are aspects to need to improve in his task, which he explains as a lack of pedagogical foundation. Thus, he has done several training processes to compensate for this deficiency.

In his Master's studies, closely linked to the PDST course, formal space for reflection was generated. There, he had the chance to rethink the way he taught and especially of systematizing what he did in the classroom.

“...doing the paper was an essential part of my reflection. If I change my way of teaching mathematics and make it more practical and more interesting for the students... But still have always seen that I need to gain the students' respect and although I feel I have improved compared to the beginning, I know that I still have much to improve...” (Interview 2, Case 02)

Seem from the outside, the process does not look successful, as manifested by the school coordinator:

“...Jorge does not have proper group management and does not set limits in class. We have talked to him, and we have done pedagogical mentoring with him. He has always shown a willingness, but still does not know how to solve his classroom problems." (Interview with Coordinator, Case 02)

The previous analysis shows that Jorge's reflection processes have somehow changed the way he understands the practice, which means he can improve it, but this is a slow process that requires more work from Jorge. His reflexive attitude and willingness are essential elements to continue developing. 


\subsection{Case 3. Teacher Flor}

Flor has been a teacher in higher education for more than ten years. She is a professional engineer and is very enthusiastic. Since she started teaching the first day, she realized and liked being a teacher; she always looked for her students' best strategies to learn.

She has two Master's degrees in specific topics of her discipline and currently works at a university in Bogota. She is the director of an engineering program and teacher of a course in the first semester. The Master's on education was recommended by other program directors and was an opportunity to get trained in pedagogy and improve her practice.

Although her field of action was higher education, Flor identified in several experiences that there were difficulties in the teaching of science, technology, engineering, and mathematics (STEM) in primary and middle school:

“...one day, I went to an event where they were promoting engineering programs for school students, and I was surprised to see those very few students were interested in the information about our programs. I tried to understand why, and I realized that the children did not consider their experience with science teachers at school was good." (Interview 1, Case 03)

Considering the importance of the training in this educative level, Flor decided to develop her Master's paper on finding strategies to improve STEM education.

In the PDST course, she could identify new elements for the teaching of STEM. For example, she understood that the disciplinary contents go beyond the classroom and that the way they are approached influences children's decisions in the future:

“...not having that scientific literacy has brought us where we are (...) As citizens, we must understand science beyond contents; we must understand the implications of science in our exercise as citizens" (Interview 2, Case 03)

"The definitions of scientific thinking adopted in this course give different understandings of the way of teaching science (...) and the opportunity of educating upstanding citizens, whose actions are oriented by science as members of society." (Final reflection of the course, Case 03)

Also, it generated reflections about the way in which science is taught:

"The use of scientific models implies following certain steps. When there is no awareness of what steps were taken to arrive at a specific model, those are perceived as easy simplifications of actual situations. Unfortunately, those steps are not explained to those who approach science, giving the impression that the problems are made easy out of convenience." (Final reflection of the course, Case 03)

The analysis identified that Flor had limited conceptions of the concepts studied at the beginning of the course. Particularly, in the Likert-type test, she expressed: "Science is a path to truth, in some moments upstanding individuals can develop it and in others by groups of specialists". Also, she disagreed with the statement that science is a lineal accumulation of discoveries.

Regarding the teaching of science, Flor agreed that to teach it, one must trust the contents of science teaching books and that it is necessary to approach the history and epistemology of science. Furthermore, she disagreed with the statement that the science teacher training must be aimed at elaborating models on how this discipline is learned.

About scientific thought, she said:

"For me, scientific thought is the ability to understand topics and/or concepts based on the knowledge acquired previously. It is necessary to have inquiry/research by the students, and they must have supported: teachers, assistants, tutors, libraries, scientific journals..." (Questionnaire 1, Case 03)

Likewise, Flor sees scientific thought in her discipline as the relations between previous concepts and knowledge building by means of answering questions, inquiring, researching, and mentoring. Similarly, she thinks that she contributes to her students' scientific thinking by implementing problem-based learning (PBL) strategies.

Flor defines the scientific community as a group of people who think in a scientific manner and who are experts in a particular discipline. These experts have their own language. Part of a teacher's work is to familiarize the students with this language.

At the end of the course, she showed a broader comprehension of NOS: "Science is a human construction in which history and the moment play an important role" (Final reflection of the module, Case 03). After all the work is done, she thinks that agreeing about what science actually is and reflecting on what encourages scientific thinking gives a broader and more contextualized view of the discipline. For example, one of the most critical understandings resulting from the course was that scientific models are an essential product of thinking and that they are the result of representations of reality: 
"It is amazing that after all the years of education in engineering that I have, no one ever explained what a scientific model is. Hence, I always accepted what was taught to me as if it were the law." (Reflections on the discussion modules, Case 03)

Besides, she makes crucial criticisms of the way science is taught in higher education:

“... maybe our flaw is not showing the use of knowledge beyond the classroom. Universities teach based on learning for the class and not for life. It is as if they went to university to pass subjects and not get prepared for what they will be doing for an important part of their lives. " (Final module reflection, Case 03)

Flor's class planning takes into account in the first place the aspects that she considers most relevant to teach her discipline. Given that the course she teaches is of basic level, she is very concerned about incorporating aspects that are actually relevant for the level and their future performance in the program. Flor has learned a lot in the course and the Master's program. Hence, she has decided on leading her class based on the strategy: Project Oriented Problem Based Learning (PO-PBL).

This strategy uses the same methodology as the PDST course, in which the students identify a problem related to the discipline and develop a group project during the course to solve it.

Besides, and as a complement to the project and the study of the topics proposed for the course, they invite experts to offer talks or workshops.

The pedagogical proposal proposed by Flor encourages a permanent relationship with the identity of the scientific community. It is evident in both the approach to the students' problems identify and the activities they develop. For instance, it identified that the experts invited to the class become facilitators and consultants in the projects according to their specialty:

"the groups developed their projects, consulting professionals, and technicians in different areas. As they explain their ideas to more experienced people, their communication skills are strengthened. Both teachers and experts are bridges between the concepts and the problems addressed. All this is projected towards the final presentation of the course." (Field journal, Class 4)

Also, lab activities are conducted frequently to strengthen some of the topics addressed in class. In general, the activities proposed by Flor are structured on the foundation of active learning and the particular dynamic of the community.

Flor gives unique value to collaborative work and making questions. She thinks that answering questions in a collaborative manner fosters the process of learning disciplinary concepts. It was confirmed by a survey perception recorded by most of the students that took the course in different semesters:

Student 1: "It is a multidisciplinary course. I learned many things that make me more enthusiastic about every dimension of my program and understand how everything is related."

Student 26: "The course gives a vision of each of the program's research areas, offering a clear perspective of its objective."

Student 20: "The activities of the course strengthened my academic abilities and my communication and teamwork skills."

However, in the same survey, some students said that their experience was not that positive:

Student 15: "The ideas were too complicated for a first-semester student."

Student 27: "When you start, you do not know much, so what you manage to research for the project is not much."

Concerning the course structure, Flor has made a special effort to propose a pedagogical approach that responds to her students' needs. She is convinced that she can attain better learning in her students. In this regard, she states:

"In my experience as a teacher, I can see how this type of activity generates interest in the group to solve the question asked. The student or the groups inquire continuously about the problems they constantly find (...) normally, these groups remain together throughout the semester and end up being close friends." (Interview 1, Case 03)

In line with this, most students express that this structure is appropriate and they say that the proposal based on PBL or PO-PBL is a great learning opportunity because it makes them apply the knowledge they acquire in the course:

Student 33: "For me, this is a good strategy. I learn more than in lectures. We learn more about each topic by means of cases because they make us apply the knowledge acquired in class."

Student 17: "The course is excellent. The projects and tasks are of great help to understand what the career is about more deeply." 
Student 20: "I think that PBL provides good tools that enable probing in the topics addressed in class."

Collaborative work encourages strong interactions between the teacher and the students and between students. In this sense, the class observations revealed a setting in which the processes of negotiation of meaning are permanent.

Although the teacher does some individual written evaluations, the robust evaluation process is closely linked to the project's development. During the classes, there was permanent feedback on the progress. This feedback not only refers to the contributions of the teacher but also to the contributions of other classmates.

"In the class I teach, we choose closed questions for the test and some open questions with the restricted length for the answer. We do this to ease the correction. Nonetheless, the test is not the main instrument to measure scientific thinking; the main ways to evaluate the course are: project development, lab reports, and presentation of the project in an event outside the classroom and organized in the program." (Interview 2-Case 03)

The reflection on Flor's pedagogical practice has been a permanent aspect since the beginning of her teaching practice. However, she has not always been aware of it, as is the case of many other university teachers or those lacking pedagogical training, whose experience has been mainly trial and error.

Hence, she has no records of her reflections but recognizes that the Master's training and the course have given her elements to identify the importance of her practice's systematization and the external support she can seek for this proposal.

"....since I started working as a teacher, I have always reflected on ways of doing it better. For me, it is of most importance to think about how to do it better." (Interview 2, Case 3)

\section{Discussion}

This section will present a cross-analysis of the cases based on the four categories of analysis proposed.

\subsection{Context and Motivation}

The cases under study represent three typical examples of teachers in the context of Colombian education: one teacher trained as a science teacher, who likes her work and is committed to improving day by day; a teacher with a degree in the discipline, who ended up being a teacher for the convenience of having economic stability and has problems communicating his ideas; a third teacher with a degree in the discipline as well, who likes teaching, characterized for her passion for her work and who found in teaching an opportunity to develop herself professionally (see Table 3 ).

Table 3. Description of the context and motivation per case

\begin{tabular}{|c|c|c|c|c|c|c|}
\hline Case & Context & $\begin{array}{c}\text { Years of } \\
\text { experience }\end{array}$ & Education & Motivation & $\begin{array}{l}\text { Personal } \\
\text { features }\end{array}$ & $\begin{array}{c}\text { Knowledge of } \\
\text { NOS, history, and } \\
\text { epistemology of } \\
\text { science }\end{array}$ \\
\hline Sol & $\begin{array}{l}\text { A primary and } \\
\text { middle school } \\
\text { in public inst. }\end{array}$ & 16 years & $\begin{array}{l}\text { Degree in } \\
\text { chemistry }\end{array}$ & $\begin{array}{l}\text { Sees in education } \\
\text { an alternative to } \\
\text { build a better } \\
\text { society. }\end{array}$ & $\begin{array}{l}\text { Kind, sound, } \\
\text { and calm. }\end{array}$ & No training \\
\hline Jorge & $\begin{array}{l}\text { A primary and } \\
\text { middle school } \\
\text { in a public } \\
\text { institution }\end{array}$ & 6 years & Engineer & $\begin{array}{l}\text { Loves } \\
\text { mathematics, it is a } \\
\text { good work option. }\end{array}$ & Shy and sound. & No training \\
\hline Flor & University & 10 years & Engineer & $\begin{array}{l}\text { Passion } \\
\text { teaching }\end{array}$ & $\begin{array}{l}\text { Entrepreneur, } \\
\text { enthusiastic, } \\
\text { kind }\end{array}$ & No training \\
\hline
\end{tabular}

\section{Source: own elaboration}

Although the three teachers work in different contexts and have different personal features, their common ground is the intuitive development of their teaching practices at the beginning of their careers and the lack of training in history and epistemology of science.

Literature has recognized these coincidences as the principal causes for the prevalence of decontextualized practices focused on the transmission of concepts (Cofré et al., 2015; Gallego et al., 2014; Gallego Badillo et al., 2004; Michel \& Neumann, 2016). Thus, finding a solution to this problem implies addressing two critical issues in the science teacher training programs at different levels: i) Find strategies that include NOS, history, and philosophy of science in the 
learning processes of the discipline (Izquierdo et al., 2016; Moreira, 2004; Salinas et al., 2000; Vallejo, 2014) and ii) develop mentoring programs that contribute to the teachers' practice and generate reflection about it (Elliot, 2000; Vélaz, 2009).

\subsection{Transformation of the Comprehensions of the Concepts of Science, Scientific Thinking, and Scientific Community}

In this category, we describe the changes in the teacher's understandings of the understudy after their training process, using the views of science proposed by Porlán (1989). Figure 1 shows a general analysis of the teachers' understandings about the concepts studied at the beginning and the end of the course. According to the figure, the teachers went from having rationalistic understandings (1) to alternative understandings (4) of the concepts of science and scientific community, as well as an increase in the amount and density of words associated with these concepts (See Tables 4 and 5). Regarding the concept of scientific thinking, there was a change from moderate empiricism (3) towards alternative views (4).

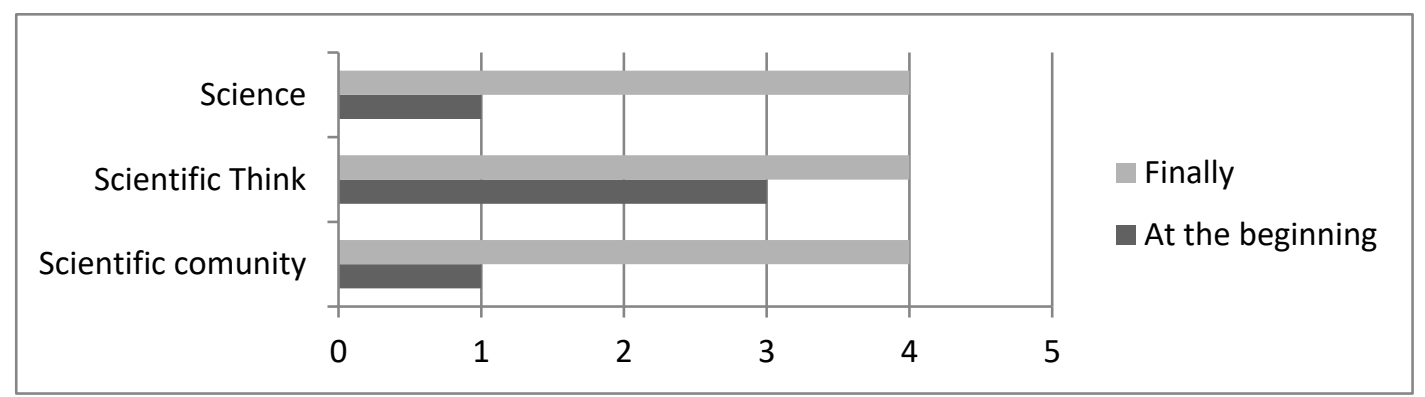

Figure 1. Transformation of the understandings of Science, Scientific Thinking and Scientific Community according to Porlán's (1989) classification at the beginning and the end of the course.

Source: Own production

Tables 4 and 5 show the specific changes in the comprehension of the three teachers. For example, in Jorge's case, he included the social, historical, and NOS dimensions in his discourse at the end, which means that he went from a rationalistic to an alternative view. On the other hand, Flor went from moderate empiricist to alternative comprehensions; after the process, her science concept was more complex, and she recognized it as a human product coming from a collective construction. Besides, she identified the importance of knowing history and NOS to teach science to approach the concepts from different dimensions. 
Table 4. Initial understandings of science and scientific thinking

\begin{tabular}{|c|c|c|}
\hline Case & Quotes & $\begin{array}{l}\text { Type of comprehension } \\
\text { (Porlán, 1989) }\end{array}$ \\
\hline Sol & $\begin{array}{l}\text { "Science is a path to truth"; "upstanding individuals make science"; } \\
\text { "science is not a linear accumulation of discoveries" (Questionnaire 1, } \\
\text { Case 01); "the way in which cognitive abilities have been developed, } \\
\text { which enables someone to understand the processes of living things and } \\
\text { their surroundings. Some abilities are related to aspects such as: asking } \\
\text { questions, analysis, synthesis, speculation, verification, contrast, and } \\
\text { communication" (Questionnaire } 2 \text { and 3, Case } 01 \text { ). }\end{array}$ & Rationalistic \\
\hline Jorge & $\begin{array}{l}\text { "Science is a path to truth" "science is not a product of groups of } \\
\text { specialists" (Questionnaire 1, Case 2). "It is the ability to think in a } \\
\text { way nature itself provides the necessary tools to solve our problems. It } \\
\text { is the ability to think in a way that nature itself gives us the necessary } \\
\text { tools to solve our problems. It is a way to see the world with the idea } \\
\text { of explaining it by means of theories that have sound foundations; in } \\
\text { other words, that they can be demonstrated or experimented with } \\
\text { being proven and verified according to the community in which we } \\
\text { are." (Questionnaire } 2 \text { and 3, Case 02) }\end{array}$ & Rationalistic \\
\hline Flor & $\begin{array}{l}\text { "Science is a path to truth, in some moments it can be developed by } \\
\text { upstanding individuals and in others by groups of specialists" } \\
\text { (Questionnaires } 2 \text { and } 3 \text {, Case 03); "For me, scientific thought is the } \\
\text { ability of understanding topics and/or concepts based on the } \\
\text { knowledge acquired previously. It is necessary to have } \\
\text { inquiry/research by the students, and they must have supported: } \\
\text { teachers, assistants, tutors, libraries, scientific journals..." } \\
\text { (Questionnaires } 2 \text { and 3, Case 03) }\end{array}$ & Moderate empiricism \\
\hline
\end{tabular}

Source: Own elaboration

Table 5 Final comprehensions of science and scientific thinking

\begin{tabular}{|c|c|c|}
\hline Case & Quotes & $\begin{array}{l}\text { Type of comprehensions } \\
\text { (Porlán, 1989) }\end{array}$ \\
\hline Sol & $\begin{array}{l}\text { science is a rational construction that enables inquiring about the logic } \\
\text { structure of the phenomena that rule nature and build explanatory } \\
\text { models in the classroom (...) It also proposes that scientific knowledge } \\
\text { can be produced by a collective process; this implies the students' active } \\
\text { participation to empower their own process..." (Final reflection of the } \\
\text { course, Case } 01) \text {; "...epistemology (...) is a clear invitation to analyze } \\
\text { the process of science throughout time and its relation with the present } \\
\text { time. Likewise, it enables us to identify the mechanisms to change } \\
\text { paradigms and improve classroom strategies." (Discussion Forum } 2 \text {, } \\
\text { Case } 01 \text { ) }\end{array}$ & Alternative \\
\hline Jorge & $\begin{array}{l}\text { "Science is made by the social groups that comprise it, its scientific } \\
\text { groups, and the way the new members form a community." (Forum } \\
\text { Module } 4 \text {, Case } 02 \text { ); "...I learned how important is the history and the } \\
\text { epistemology of a specific science; sometimes we do not know this and } \\
\text { it can show us the obstacles that humanity has had to solve a problem } \\
\text { (...) this is very important because it is a motivation factor for the } \\
\text { students. (Final reflection, Case 02) }\end{array}$ & Alternative \\
\hline Flor & $\begin{array}{l}\text { "Science is a human construction in which history and the moment } \\
\text { play an important role" (Final reflection of the module, Case 03). It is } \\
\text { fantastic that after all the years of education in engineering that I have, } \\
\text { no one ever explained what a scientific model is. Hence, I always } \\
\text { accepted what was taught to me as if it were the law." (Reflections on } \\
\text { the discussion modules, Case 03) }\end{array}$ & Alternative \\
\hline
\end{tabular}


A NOS approach fosters the contextualization of knowledge and enables better learning in the students (Martínez C. \& Jirón, 2012). In other words, if teachers understand the importance of this approach for their task, they will identify more easily how they can familiarize their students with the practice of the scientific community: solving problems, arguments by negotiation of meanings (Rivarosa \& Astudillo, 2013; Vásquez, Acevedo, Manassero, \& Acevedo, 2001; Wenger, 1998).

\subsection{Sociocultural Comprehensions and Development of the Pedagogical Practice}

According to Carr (1995), pedagogical practices must be studied from the inside, by identifying three aspects: the teacher's intentions, the interactions that he/she generates with the students in the activities he/she proposes, and the context of the teacher, the discipline and the students. We will explain the complexity of this view addressing each one of the sub-categories proposed.

\subsubsection{Criteria and Intentions for Course Planning.}

In this sub-category, we analyze the teachers' ways and resources used in planning his/her classes. The information collected at the beginning of the course showed that the primary resources for class planning were the following in order of importance: classic disciplinary contents, guidelines of the Ministry of Education, and guidelines of the particular institution.

Table 6. Criteria and intentions for class planning in each case

\begin{tabular}{l|l|l|l}
\hline \multicolumn{1}{c|}{ Case } & \multicolumn{1}{|c|}{ Before } & \multicolumn{1}{c}{ After } & \multicolumn{1}{c}{ Quotes } \\
\hline Sol & $\begin{array}{l}\text { Classic disciplinary contents } \\
\text { (books), guidelines from the } \\
\text { Ministry of Education, and } \\
\text { guidelines from the } \\
\text { institution. }\end{array}$ & $\begin{array}{l}\text { Scientific thinking skills, } \\
\text { global competences in the } \\
\text { discipline, and main problems } \\
\text { or questions of the particular } \\
\text { discipline. }\end{array}$ & $\begin{array}{l}\text { "Before I used to work on a lineal } \\
\text { sequence of contents, everything was } \\
\text { quite flat, like it lacked sense... The thing } \\
\text { is I have to cover a wide range of } \\
\text { planned contents, so you devote to the } \\
\text { topics but not to the thinking." (Interview } \\
\text { 2, Case 01). }\end{array}$ \\
\hline Jorge & $\begin{array}{l}\text { The classic sequence of } \\
\text { contents (Book). Guidelines } \\
\text { of the Ministry of Education } \\
\text { and the particular school. }\end{array}$ & $\begin{array}{l}\text { Although he recognizes the } \\
\text { importance of NOS, changes } \\
\text { are not visible in his planning. }\end{array}$ & $\begin{array}{l}\text { "..For the planning, we take into } \\
\text { account the topics, the guidelines from } \\
\text { the Ministry for mathematics and the } \\
\text { school (...) explanation of concepts } \\
\text { regarding certain topics, and doing the } \\
\text { exercises correctly." (Interview 1, Case } \\
\text { 02). }\end{array}$ \\
\hline Flor & $\begin{array}{l}\text { Contents according to the } \\
\text { guidelines of the program } \\
\text { and the institution. }\end{array}$ & $\begin{array}{l}\text { Theories that are the } \\
\text { foundation of the discipline, } \\
\text { international competences, } \\
\text { problems typical of the } \\
\text { discipline }\end{array}$ & $\begin{array}{l}\text { ".. maybe our flaw is not showing the } \\
\text { use of knowledge beyond the classroom. } \\
\text { Universities teach based on learning for } \\
\text { the class and not for life. It is as if they } \\
\text { went to university to pass subjects and } \\
\text { not get prepared for what they will be } \\
\text { doing for an important part of their } \\
\text { lives." (Final module reflection, Case } \\
\text { 03). }\end{array}$ \\
\hline
\end{tabular}

Source: own elaboration

In contrast, at the end of the course, the analysis of the pedagogical practices and the responses of Sol and Flor show that their criteria for planning changed and included scientific thinking skills, global competences of the discipline, and problems or main question of the discipline (See Table 6 and Figure 2). In Jorge's case, there was no evidence of change; the teacher continued to plan his classes considering textbooks contents as his main guideline. According to Martínez and Rodríguez (2010), textbooks are still the predominant pedagogical device for curricular development in the classroom of education institutions at different levels. In this sense, books are artifacts (Radford L., 2003; Roth, Mcginn, \& Roth, 2009; Wenger, 1998) that materialize a pedagogical approach in line with a specific cultural tradition; hence, using a book in the classroom guides the pedagogical practice (Gimeno, 1995; Martinez \& Rodríguez, 2010).

4.3.2 Strategies to Familiarize Students With the Identity of the Scientific Community

In this sub-category, we analyzed the type of strategies and activities used by the teachers in their practices to make the students familiar with the roles of the members of the scientific community. The changes in Sol and Flor showed changes in 
the strategies they used at the beginning of the process (see Table 7). Practices as developing projects, modeling exercises, experiments, lab practices, and moments of socialization and discussion involve the students in the scientific community's activities and help them find identities in this community that can be interesting and become an actual possibility.

Table 7. Strategies to bring the students closer to the identity of the scientific community

\begin{tabular}{l|l|l|l}
\hline Case & \multicolumn{1}{|c|}{ Before } & \multicolumn{1}{c|}{ After } & \multicolumn{1}{c}{ Quotes } \\
\hline Sol & $\begin{array}{l}\text { Lectures and } \\
\text { demonstrative } \\
\text { practices in the lab. }\end{array}$ & $\begin{array}{l}\text { Asking questions, lab practices, } \\
\text { presentation of models, } \\
\text { mini-projects, experimental } \\
\text { demonstrations. }\end{array}$ & $\begin{array}{l}\text { "the teacher asks every student to make a 3D model } \\
\text { of a bone in plasticine. She clarifies that the model } \\
\text { must show the different parts of the bone...” (Field } \\
\text { journal - Class 3, Case 01) }\end{array}$ \\
\hline Jorge & $\begin{array}{l}\text { Decontextualized } \\
\text { exercises }\end{array}$ & $\begin{array}{l}\text { No evidence of change } \\
\text { “..the teacher explained four examples of exercises } \\
\text { on the board about the topic: multiplication of } \\
\text { polynomial functions. Here I would like to highlight } \\
\text { that few students are paying attention to the } \\
\text { explanation, but the teacher is not aware of this...” } \\
\text { (Field journal- Class 1, Case 02) }\end{array}$ \\
\hline Flor & $\begin{array}{l}\text { Lab practices and } \\
\text { pedagogical } \\
\text { journeys }\end{array}$ & $\begin{array}{l}\text { Development of projects that } \\
\text { identify and solve problems } \\
\text { typical of the discipline, experts } \\
\text { invited to class, participation in } \\
\text { disciplinary events. }\end{array}$ & $\begin{array}{l}\text { "the groups developed their projects, consulting } \\
\text { professionals, and technicians in different areas. As } \\
\text { they explain their ideas to more experienced people, } \\
\text { their communication skills are strengthened.” (Field } \\
\text { journal, Class 4). }\end{array}$ \\
\hline
\end{tabular}

Source: own elaboration
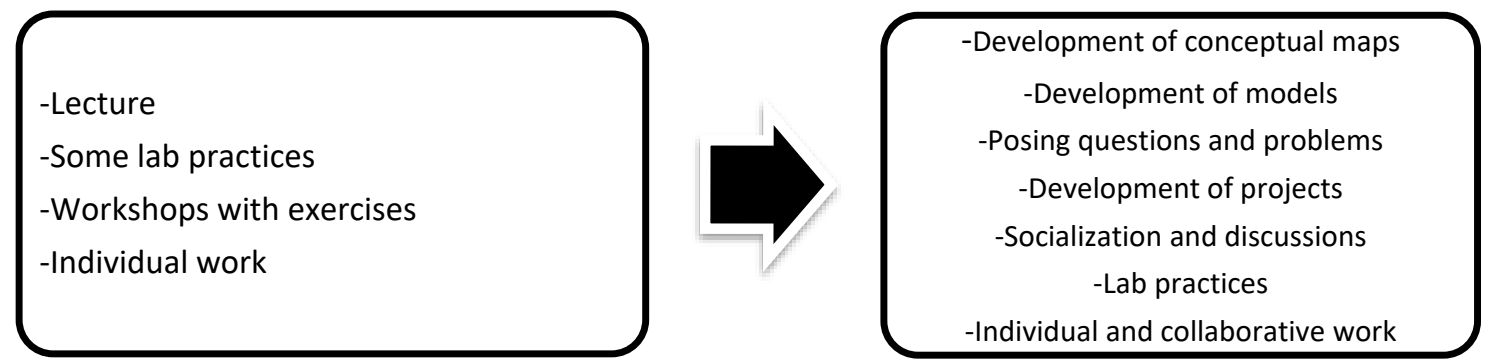

Figure 2. Comparison between the activities at the beginning and the end of the training program for Cases 01 and 03

In the case of Jorge, no evident changes were found in the activities he proposes. He mainly explains exercises on the board and promotes the development of exercises individually. Although math is considered an exact science, it is also a community product. In this sense, a sociocultural perspective of education in math implies assuming the knowledge produced in this discipline due to a social activity. Understanding the discipline from this perspective gives a view of the strategies used to teach it (Jaramillo, 2011; Radford L., 2008; Radford L., 2003). According to this, there is no evidence of a practical approach to the community's identity that builds the discipline taught by Jorge. His activities continued to reproduce a reduced vision of science, particularly mathematics.

\subsubsection{Strategies to Negotiate Meanings in Community}

In this sub-category, we analyzed the teaching that fosters learning from community participation, especially collaborative learning. According to Wenger (1998), the negotiation of meanings includes social interaction; this can happen directly or by using artifacts produced by the community. Besides, collaborative work promotes reflection about the reality based on the interaction among peers, leaving behind the transmission of concepts (Martínez, Marsiglia, Dumrauf, \& Cordero, 2009) and transforming the practice in the classroom.

In the cases of Sol and Flor, collaborative work was strengthened, and disciplinary concepts were probed by the inclusion of group projects in their practice. Sol developed them based on questions and Flor on problems. The differences in the projects' intention may be related to the level they are teaching: Sol teaches primary and middle school and Flor at the university level. Besides, the time required to apply the strategies of answering questions or solving problems was different. In the case of Flor, the problems are developed collaboratively throughout the semester. On the other hand, 
Sol's strategy is developed individually in three moments of the school period.

Another common element is collaborative work in the development of lab practices, in which the students reproduce experiments and practices of the discipline-based on guidelines and then write their reports. In addition to being typical of scientific communities, these activities are highly valued by students (see Table 8).

Table 8 . Strategies for the negotiation of meanings in the community per case.

\begin{tabular}{l|l|l|l}
\hline Case & \multicolumn{1}{|c|}{ Before } & \multicolumn{1}{|c|}{ After } & \multicolumn{1}{c}{ Quotes } \\
\hline Sol & $\begin{array}{l}\text { Activities } \\
\text { based } \\
\text { individual } \\
\text { work. }\end{array}$ & $\begin{array}{l}\text { Activities based on } \\
\text { individual work continue. } \\
\text { There are group activities } \\
\text { only in the lab. }\end{array}$ & $\begin{array}{l}\text { "I like working in individual activities because like that; I can } \\
\text { assure that each student is building their own knowledge. } \\
\text { When I make them work in groups, only a few ones end up } \\
\text { working. That is also why I ask to see their notebook } \\
\text { frequently (...) At first I used to set up the desks in a circle, } \\
\text { but that would end up in a mess..." (Interview 2, Case 01) }\end{array}$ \\
\hline Jorge & $\begin{array}{l}\text { Activities } \\
\text { based } \\
\text { individual } \\
\text { work. }\end{array}$ & $\begin{array}{l}\text { No evident changes } \\
\text { "The class starts, and the teacher does the roll-call. He } \\
\text { explains some exercises on the board and then goes place by } \\
\text { place to see what they are doing. Then, he leaves 15 exercises } \\
\text { on the board and asks the students to solve them before the } \\
\text { class is over." (Field Journal, - Class 1, Case 02) }\end{array}$ \\
\hline Flor & $\begin{array}{l}\text { Lectures and } \\
\text { workshop } \\
\text { development }\end{array}$ & $\begin{array}{l}\text { Classes } \\
\text { collaborative } \\
\text { Development of projects by } \\
\text { means of PO-PBL } \\
\text { on }\end{array}$ & $\begin{array}{l}\text { "In my experience as a teacher, I can identify how this type of } \\
\text { activity generates interest in solving the question asked in the } \\
\text { group. The student or the groups inquire continuously about } \\
\text { the problems they constantly find (...) normally, these groups } \\
\text { remain together throughout the semester and end up being } \\
\text { close friends." (Interview 1, Case 03) }\end{array}$ \\
\hline
\end{tabular}

Source: Own elaboration

In Jorge's case, he did not introduce any kind of activity implying collaborative work, despite his manifestations about being willing to do it. This can be due to the difficulties of the teacher in his management of the group. For Jorge, this kind of activity makes him lose control over the group more easily.

Sol shares this idea of losing control over the group with Jorge, which reveals the need to strengthen the practical implications of collaborative practices in teacher training (Ramos, 2006) to handle better the emotional processes involved in such changes.

\subsubsection{The Approach of Disciplinary Concepts and Scientific Thinking}

In this sub-category, we identified how teachers teach the concepts of a particular discipline and scientific thinking. This analysis reveals the historical context and the teacher's approach to science's nature when teaching contents in their practice. In particular, we refer to the way the teacher includes the topics of nature, history, and philosophy of science in the disciplinary concepts taught.

A common fact is that none of the teachers had had any training in this area in previous training experiences. Although they showed changes in their comprehension of science and manifested in several moments that they had understood the importance of topics related to the NOS that they teach, it was challenging for them to take these ideas into their practice.

This fact is consistent with Mellado and González (2000) reports, who identified even in teachers who have undergone specific training in philosophy and history of science, that they will not put it into practice unless they have a piece of functional and comprehensive knowledge in this regard. Thus, there is a need to build a strategy that includes and fosters the combination of NOS and concepts as specific activities in the science teaching practice (Cofré, Cuevas, \& Becerra, 2017; Michel \& Neumann, 2016).

One possible way of doing it is including mentoring processes in the different stages of teacher training, involving among other topics- the implications of the NOS and specific contents of the particular discipline. These programs are an excellent opportunity to guarantee better training processes at different levels (Barrera, Maldonado, \& Rodriguez, 2012; Vélaz, 2009).

\subsubsection{Strategies to Evaluate Learning}

To close this category, we analyzed the evaluation strategies used in practice and the coherence of such strategies with the teaching proposal. The analysis showed that as the classroom proposed activities became enriched, there were also more 
chances for evaluation than the initial scenarios when the teachers started their training. Sol and Flor included strategies to evaluate collective work, argumentation skills, and problem solutions. Besides, permanent feedback in class could be observed. As in the previous sub-categories, in Jorge's case, there was no evidence of integration of new evaluation strategies in his pedagogical practice (see Table 9 and Figure 3).

Table 9. Strategies for the evaluation of learning

\begin{tabular}{lll}
\hline Case & \multicolumn{1}{c}{ Before } & \multicolumn{1}{c}{ After } \\
\hline Sol & $\begin{array}{l}\text { Evaluation of activities in the notebook, lab } \\
\text { reports, and tests with open and closed questions } \\
\text { about the contents taught. }\end{array}$ & $\begin{array}{l}\text { Review of workshops in the notebook, } \\
\text { written or virtual tests per } \\
\text { competences, lab reports, mini-projects } \\
\text { (observation and argumentation skills). }\end{array}$ \\
Jorge $\quad \begin{array}{l}\text { Decontextualized strategies, grades the } \\
\text { development of a list of exercises in the notebook } \\
\text { (He calls these workshops in class). Written tests } \\
\text { based on class exercises. } \\
\text { Workshops, tests with open and closed questions, } \\
\text { exhibitions. }\end{array}$ & $\begin{array}{l}\text { Novelopment of research projects, } \\
\text { collaborative work, argumentation } \\
\text { activities, and some tests. }\end{array}$ \\
\hline
\end{tabular}

Source: own elaboration
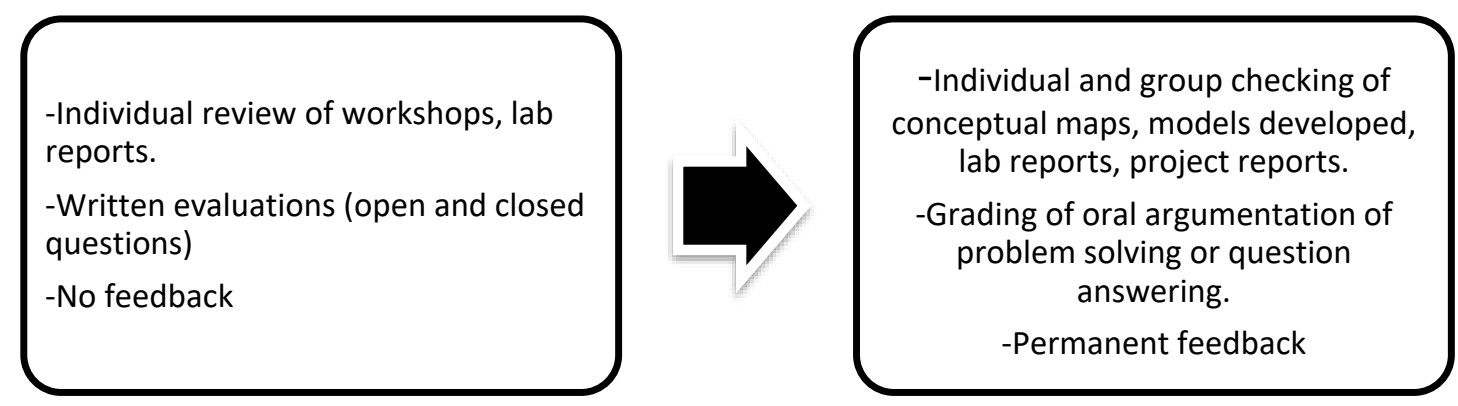

Figure 3. Changes in the evaluation strategies reported by the teachers at the beginning and the strategies identified at the end in classroom observations for the cases of Sol and Flor.

On the other hand, the evident change in science and scientific thinking comprehension affects teachers' evaluation strategies. According to the analysis, the alternative views of science promote the application of evaluation strategies to assess the development of the student's skills related to scientific thinking and not only the assimilation of contents (Rodriguez, 2016).

\subsubsection{Contributions to the Processes of Reflection on the Practice}

In this category, we identified reflexive processes in the teachers and the systematization strategies resulting from such processes. According to Stenhouse (1998), every class is a setting for learning and research for the teachers, who must put it into a test to verify their proposal and make permanent adjustments. Thus, the teacher will understand their own task in detail and will appropriate this task developing plans to perfect their teaching and learning practices holistically.

In this analysis, we found that at the beginning of the training in the three cases, there was an informal reflection on their duty, which happened automatically with no specific records and no concern for arguing from a pedagogical knowledge; this is why it has no transcendence (Stenhouse, 1998).

As they started their training program, they became familiar with the formal systematization of their practices by means of field journals, which gave them access to information about their performance. Nonetheless, they used this instrument strictly during the time of the training and not after it. Although they find it very useful, they think they do not have the time to keep this record.

Our cases reveal that teachers are not used to doing a systematic process of reflection on their practice in the classroom. Most of them see it as something external and not a core aspect of their duty that must be addressed from the teacher training programs' beginning. A systematic reflection on the practice is the best opportunity to improve its quality (Bozu, 2012). 


\section{Conclusions and Limitations}

Based on this study's results and in response to the research question, we identified different contributions to the training proposal in the different categories used to analyze the pedagogical practices.

By means of the curriculum proposed in this research study, the teachers attained not only new comprehensions of science, of the discipline they teach, and of learning itself but also found other meanings for the concepts they teach, assuming a reflexive role in their practice. In this way, they went from planning their classes based on contents, government, and institutional guidelines to planning based on scientific thinking skills, global competencies, and critical problems or questions of the discipline they teach. Moreover, it was evident that books are cultural artifacts that can foster or undermine changes in the pedagogical practice, depending on whether they include or not alternative views of the nature of science in their contents.

Significant changes were found in the class activities proposed by the teachers that included activities aimed at recognizing the identity of the scientific community, i.e., the settings where science is produced. For instance, they included in their practice developing projects and experiments, modeling exercises, lab practices, and moments of socialization and discussion.

Moreover, they also included some strategies that encourage the negotiation of meaning in the community by giving assignments for collaborative work in which both, students and teachers, interacted in the discussion of different ideas. One of these assignments was developing projects related to fundamental concepts of the particular discipline. In primary and middle school, these were implemented by posing questions and higher education by formulating problems. Another strategy was implementing lab practices in which the students were able to reproduce experiments and explore certain natural phenomena.

Regarding evaluation strategies, it was evident that as the activities proposed in the classroom became more affluent, the chances for evaluation were much more than those conceived by the teachers at the beginning of their training, including permanent feedback.

Throughout the study, we identified that the training process generated a more conscious reflection on the teachers' practice. The projects developed in the course were their first experience of systematization of their teaching practice. However, a limitation found a posteriori was that after the training program had officially ended, the teachers stopped systematizing their practice. For them, this is an extra activity and not a core aspect of their work as teachers.

On these grounds, and considering that most teachers currently in-service in Colombia did not have mentoring processes in the classroom during their initial training, the design of postgraduate or permanent training programs that include mentoring in their practice is imperative. This action will empower teachers in their practice and give them the necessary tools to approach problems in their classroom in a more effective way.

Finally, we would like to highlight that to transform science teachers' pedagogical practice; there is more than transforming their comprehension of science and recognizing the meaning of a sociocultural perspective of learning. An additional process is required, focused on the practice itself, enabling the teacher to bring theoretical knowledge together with what actually happens in the classroom. In other words, there is a need for pedagogical mentoring processes that help teachers putting that comprehension into practice. Nevertheless, there is still a need for a sound research line around this mentoring, which opens an entirely new research scenario in the field.

\section{References}

Alcocer, M., \& Hernández, C. (2020). Investigación en enseñanza de las ciencias en Colombia: estudio desde sus cosificaciones. Educación y Educadores, 23(1), 47-68. https://doi.org/10.5294/edu.2020.23.1.3

Alvesson, M., \& Skoldberg, K. (2009). Reflexive Methodology (SAGE). London.

Barrera, F., Maldonado, D., \& Rodriguez, C. (2012). Calidad de la educación básica y media en colombia : diagnóstico y propuestas Felipe Barrera-Osorio. Serie Documetnos de Trabajo, (126), 74.

Bozu, Z. (2012). Cómo elaborar un portafolio para mejorar la docencia universitaria. Una experiencia de la formación del profesorado novel.

Carr, W. (1995). For Education: Towards Critical Educational Inquiry, Buckingham, Open University Press.

Cofré, H., Camacho, J., Galaz, A., Jiménez, J., Santibánez, D., \& Vergara, C. (2010). La Educacion Cientifica En Chile: Debilidades De La Enseñanza Y Futuros Desafios De La Educacion De Profesores De Science. Estudios Pedagógicos XXXVI(2), 279-293. https://doi.org/10.4067/S0718-07052010000200016

Cofré, H., Cuevas, E., \& Becerra, B. (2017). The relationship between biology teachers' understanding of the nature of science and the understanding and acceptance of the theory of evolution. International Journal of Science Education, 693(September), 1-16. https://doi.org/10.1080/09500693.2017.1373410

Cofré, H., González-Weil, C., Vergara, C., Santibáñez, D., Ahumada, G., Furman, M., ... Pérez, R. (2015). Science 
Teacher Education in South America: The Case of Argentina, Colombia and Chile. Journal of Science Teacher Education, 26(1), 45-63. https://doi.org/10.1007/s10972-015-9420-9

Elliot, J. (2000). ¿En qué consiste la investigación-acción en la escuela? La Investigación-Acción En Educación, 1-20.

Gallego Badillo, R., Pérez Miranda, R., Gallego, T., \& Torres, L. (2004). Formación inicial de profesores de ciencias en Colombia: un estudio a partir de programas acreditados. Ciência \& Educação (Bauru), 10, 219-234. https://doi.org/10.1590/S1516-73132004000200006

Gallego, R., Perez, R., \& Franco, R. (2014). Transformaciones de las concepciones en la formación inicial de profesores de química (Fondo naci).

Garcia, J. (2014). A propósito de los resultados de las pruebas PISA en Colombia. Uni-Pluriversidad, 14(1), Editorial.

Garcia, S., Maldonado, D., Perry, G., Rodriguez, C., \& Saavedra, J. (2013). Tras la excelencia docente: ¿Cómo mejorar la calidad de la educación para todos los colombianos? https://doi.org/10.17227/0120391.67rce89.105

Gimeno, S. (1995). Materiales y textos: Contradiccciones de la democracia cultural. Madrid-España.

Goetz, J., \& Lecompte, M. (1988). Etnografía y diseño cualitativo en investigación educativa. (Morata.). Madrid-España.

Hernández, C. (2001). Aproximación a un estado del arte de la enseñanza de las ciencias en colombia. In c. ICFES (Ed.), Sociedad colombiana de pedagogía-SOCOLPE. Retrieved from http://www.socolpe.org/data/public/libros/InvestigacionPedagogia/2-1Ciencias-EstadodelArte.pdf

Izquierdo, M., García, Á., Quintanilla, M., \& Adúriz, A. (2016). Historia, Filosofía y Didáctica de las ciencias: Aportes para la formación del profesorado de ciencias (UD editori). Bogotá- Colombia. https://doi.org/10.14483/9789588972282

Jakku-Sihvonen, J., \& Niemi, H. (2007). Research-based teacher education in Finland: Reflections by Finnish teacher educators. Helsinki, Finland: Finish Educational Research Association.

Jaramillo, D. (2011). La educación matemática en una perspectiva sociocultural: tensiones, utopías, futuros posibles. $\begin{array}{lllll}\text { Revista Educación } & Y & \text { Pedagogía, 23(59), 13-36. } & \text { Retrieved } & \text { from }\end{array}$ http://aprendeenlinea.udea.edu.co/revistas/index.php/revistaeyp/article/view/8688

Kruse, J., Easter, J., Edgerly, H., Seebach, C., \& Patel, N. (2017). The Impact of a Course on Nature of Science Pedagogical Views and Rationales. Science \& Education, 26(9), 613-636. https://doi.org/10.1007/s11191-017-9916-0

Kutluca, A., \& Ayd, A. (2017). Changes in Pre-service Science Teachers' Understandings After Being Involved in Explicit Nature of Science and Socioscientific Argumentation Processes. Science \& Education, 26(6), 637-668. https://doi.org/10.1007/s11191-017-9919-x

Latour, B. (1987). Science in Action. Harvard University Press. Cambridge Massachusetts.

Levy, C. (1998). Sobre Las Concepciones Y Las Prácticas. Enseñanza de Las Ciencias, 269-283.

Martínez, C., Marsiglia, M., Dumrauf, A., \& Cordero, S. (2009). Innovación y trabajo colaborativo en la enseñanza de las Ciencias Naturales : una experiencia didáctica sobre los dilemas éticos del proyecto genoma humano. Revista Iberoamericana de Educación, 4(48).

Martínez, J., \& Benarroch, A. (2013). Concepciones y creencias sobre ciencia, aprendizaje y enseñanza de profesores universitarios de ciencias. ... En Educación En Ciencias, 8, 24-41. Retrieved from http://dialnet.unirioja.es/servlet/articulo?codigo $=4462806$

Martinez, J., \& Rodríguez, J. (2010). Fundamentos de una psicología El currículum y el libro de texto. Una dialéctica siempre abierta. Saberes E Incertidumbres Sobre El Currículo, 246-268.

Mellado, V., \& González, T. (2000). La formación inicial del profesorado de ciencias experimentales. Didáctica de Las Ciencias Experimentales, (January). Retrieved from https://www.researchgate.net/profile/Vicente_Mellado/publication/269150980_La_formacion_inicial_del_profesor ado_de_ciencias_experimentales/links/55a53da308aef604aa042e5c/La-formacion-inicial-del-profesorado-de-cienc ias-experimentales.pdf

Mesci, G., Schwartz, R. S., \& Pleasants, B. A (2020). Enabling Factors of Preservice Science Teachers' Pedagogical Content Knowledge for Nature of Science and Nature of Scientific Inquiry. Sci \& Educ 29, 263-297. https://doi.org/10.1007/s11191-019-00090-w

Michel, H., \& Neumann, I. (2016). Nature of Science and Science Content Learning and Their Learning About the Concept of Energy. Science \& Education, 26(9), 951-975. https://doi.org/10.1007/s11191-016-9860-4 
Ministerio de Educación Nacional MEN. (2014). La calidad en la educación depende directamente de la calidad de los profesores, los educadores y los currículos", Clare Kosnik.

Misas, G. (2004). La educación superior en Colombia: análisis y estrategias para su desarrollo. Retrieved from http://books.google.es/books?id=whvKuC2UAocC

Moreira, M. A. (2004). Investigación Básica En Educación En Ciencias: Una Visión Personal. Revista Chilena de Educación Científica, 3(1), 10-17.

Ortega, N., Ordoñez R., Gomes-Vahos J., \& Florez, M (2018). Caracterización de las prácticas pedagógicas en torno a la formación de competencias en Ciencias naturales y educación ambiental en al básica secundaria y media. Capitulo de libro en: Concepciones y prácticas en el contexto de norte de santander.

Porlán, R. (1989): Teoría del conocimiento, teoría de la enseñanza y desarrollo profesional. Las concepciones epistemológicas de los profesores. Tesis doctoral. Universidad de Sevilla.

Porlán, R., Rivero, A., \& Martín del Pozo, R. (1998). Conocimiento profesional y epistemología de los profesores, II. Ensenanza de Las Ciencias, 16(2), 271-288. Retrieved from http://ddd.uab.cat/record/1399/

Radford, L. (2003). Culture and cognition Towards an anthropology of mathematical thinking. Culture and Cognition.

Radford, L. (2008). The ethics of being and Knowing: Towards a cultural theory of learning. Semiotics in Mathematics Education: Epistemology, History, Classroom, and Culture. https://doi.org/10.1163/9789087905972_013

Ramos, T. (2006). Los científicos y su trabajo en el pensamiento de los maestros de primaria. Revista Mexicana de Investigación Educativa, 11, 1287-1306.

Rodriguez, D. (2016). La comprensión de la evaluación, un abordaje personal.

Roth, W., Mcginn, M. K., \& Roth, W. (2009). Review of Educational Research Representing as Social Practice. https://doi.org/10.3102/00346543068001035

Salinas, J., Carvalho, A. P. De, Maiztegui, A., González, E., Tricárico, H., Salinas, J., \& Gil, D. (2000). La formación de los profesores de ciencias en iberoamérica. Revista Iberoam, 163-187.

Shapin, S., \& Schaffer, S. (1985). Leviathan and the air-pump (Princeton).

Stake, R. (1995). The art of case study research. Sage publication

Stenhouse, L. (1998). La investigación como base de la enseñanza (Ediciones). Madrid España.

Torres, A., Badillo, R., \& Miranda, R. (2006). Qué versión de ciencia se enseña en el aula? Educación Y Educadores, 105-116. Retrieved from

http://scholar.google.com/scholar?hl=en\&btnG=Search\&q=intitle:?Qu?+versi?n+de+ciencia+se+ense?a+en+el+au la?\#0

Vallejo, S. (2014). Las competencias científicas en la política educativa colombiana: Privilegio de la perspectiva parcial al estudiar su ensamblaje desde los Estudios Sociales Las competencias científicas en la política educativa colombiana : Privilegio de la perspectiva $\mathrm{p}$.

Vasco, C. (1993). Enseñanza de las ciencias. Perspectivas Para Una Escuela Del Mañana. Bogotá- Colombia: Asociación colombia para el avance de la ciencia A.C.A.C.

Vázquez, A., Acevedo, J. A., \& Manasero, M. (2000). Consensos sobre la Naturaleza de las Ciencias. Revista Iberoamericana de Educación, ISSN: 1681.

Vélaz, C. (2009). Competencias del profesor - mentor para el acompañamiento al profesorado principiante. Revista de Currículum Y Formación Del Profesorado, 13(1), 209-229.

Wenger, E. (1998). Communities of practice: learning, meaning, and identity. (University of Cambridge, Ed.). Cambridge, Reino Unido. https://doi.org/10.1017/CBO9780511803932

Yin, R. (2009). Case Study h Research Design and Methods Fourth Edition. Road: GAGE L.td.

Zambrano, C. (2015). Estatuto epistemologíco de la investigación en educación en ciencias 2000-2011. (U. el Valle, Ed.). Cali-Valle-Colombia.

\section{Copyrights}

Copyright for this article is retained by the author(s), with first publication rights granted to the journal.

This is an open-access article distributed under the terms and conditions of the Creative Commons Attribution license which permits unrestricted use, distribution, and reproduction in any medium, provided the original work is properly cited. 